\title{
STIGMA DAN DISKRIMINASI PADA ANAK DENGAN HIV AIDS (ADHA) DI SEPULUH KABUPATEN/KOTA DI INDONESIA
}

\section{Stigma and Discrimination among Children With HIV/AIDS in Ten Districts in Indonesia}

\author{
Sugiharti $^{1 *}$, Rini Sasanti Handayani ${ }^{2}$, Heny Lestary $^{1}$, Mujiati $^{2}$, Andi Leny Susyanti ${ }^{2}$ \\ ${ }^{1}$ Pusat Penelitian dan Pengembangan Upaya Kesehatan Masyarakat, Badan Litbangkes \\ ${ }^{2}$ Pusat Penelitian dan Pengembangan Sumber Daya dan Pelayanan Kesehatan, Badan Litbangkes \\ *Email: sg_atik@yahoo.co.id
}

Naskah masuk 19 November 2019; review 4 Desember 2019; disetujui terbit 31 Desember 2019

\begin{abstract}
Background: Children with HIV are vulnerable groups that need to be protected, considering that their parents have often died of HIV/AIDS.

Objective: The purpose is to find information about stigma and discrimination against children with HIV/AIDS in 10 districts in Indonesia.

Method: The study was conducted in 2015 with a cross-sectional research design using quantitative and qualitative combined approaches (mixed methods approaches). Quantitative study respondents were parents/guardians of children with HIV/AIDS aged $\geq 18$ months totaling 201 children with HIV/AIDS. The variables studied included: age, child status, children with HIV/AIDS companion and source of transmission), reasons for closing the ADHA status and reasons for opening status. The qualitative study informants were doctors, nurses, case managers, NGOs, and the Education Office

Results: Quantitative results showed that $41.8 \%$ of children with HIV/AIDS were aged 4-9 years; $58.5 \%$ are in school; $61.7 \%$ of children with HIV/AIDS companions are biological parents; $91.5 \%$ of sources of transmission are from biological mothers; $57.5 \%$ of reasons for closing status because of shame/stigma/ discrimination, $45.9 \%$ of reasons for opening status because the family already knew. Qualitative results of stigma and discrimination occur in families, the environment, schools, and health services

Conclusion: Children with HIV/AIDS are a vulnerable group that must be protected. They have the right to live properly and safely like other children. But the results of this study found that there was still stigma and discrimination for Children with HIVIAIDS, both in the home, school and health care facilities.
\end{abstract}

Key words: Children with HIV/AIDS, Stigma and Discrimination, HIV/AIDS

\begin{abstract}
Abstrak
Latar belakang: Anak dengan HIV merupakan kelompok rentan yang perlu dilindungi, mengingat orang tua mereka sering kali sudah meninggal karena HIV/AIDS.

Tujuan: mengetahui gambaran stigma dan diskriminasi pada Anak dengan HIV/AIDS (ADHA) pada 10 Kabupaten/Kota di Indonesia.

Metode: Penelitian dilakukan tahun 2015 dengan disain potong lintang, menggunakan pendekatan kuantitatif dan kualitatif (mixed methods approaches). Responden studi kuantitatif adalah orangtua/wali dengan ADHA berusia $\geq 18$ bulan sejumlah 201 ADHA yang diperoleh dari Dinas Kesehatan. Variabel yang diteliti meliputi: usia, status anak, pendamping ADHA dan sumber penularan), alasan menutup status ADHA dan alasan membuka status. Informan studi kualitatif adalah adalah dokter, perawat, manajer kasus, LSM, dan Dinas Pendidikan

Hasil: Hasil kuantitatif menunjukkan 41,8\% ADHA di usia 4-9 tahun; 58,5\% berstatus sekolah; 61,7\% pendamping ADHA adalah orangtua kandung; 91,5\% sumber penularan berasal dari ibu kandung; 57,5\% alasan menutup status karena malu/stigma/diskriminasi, 45,9\% alasan membuka status karena keluarga sudah tahu. Hasil kualitatif bahwa stigma/ diskriminasi terjadi di keluarga, lingkungan sekitar, sekolah dan pelayanan kesehatan.

Kesimpulan: ADHA merupakan kelompok rentan yang harus dilindungi. Mereka berhak untuk dapat hidup dengan layak dan aman seperti anak - anak lainnya. Namun hasil penelitian ini menemukan masih terjadi stigma dan diskriminasi bagi ADHA, baik di lingkungan rumah, sekolah, maupun fasilitas pelayanan kesehatan.
\end{abstract}

Kata kunci: ADHA, Stigma dan Diskriminasi, HIV-AIDS 


\section{PENDAHULUAN}

Laporan United Nation Internationa Children's Emergency Fund (UNICEF) Indonesia tahun 2012 menyatakan bahwa diperkirakan tiap 25 menit terdapat 1 orang baru terinfeksi HIV. Satu dari lima orang yang terinfeksi di bawah usia 25 tahun. ${ }^{1}$ Proyeksi Kementerian Kesehatan menunjukkan bahwa tanpa percepatan program penanggulangan HIV, maka diperkirakan setengah juta orang di Indonesia akan positif HIV pada tahun 2014. Laporan Pengendalian Penyakit dan Penyehatan Lingkungan per September tahun 2013 menyebutkan jumlah anak terinfeksi HIV usia $\leq$ 14 tahun sebesar 3.080 (3,64\%) dan 15-19 tahun sebesar $2.908(3,44 \%)$. Anak usia $\leq 14$ tahun yang menerima Anti Retroviral Virus (ARV) adalah 76,7 persen. Dengan demikian terdapat $23,3 \%$ anak usia $\leq 14$ tahun yang membutuhkan ARV tidak mendapatkan layanan tersebut. $^{2}$

Kementerian Kesehatan telah memproyeksikan peningkatan infeksi pada anak-anak, seiring dengan meningkatnya infeksi HIV baru pada perempuan. Temuan awal studi terakhir yang dilakukan oleh UNICEF dan Komisi Penanggulangan AIDS Nasional (KPAN) menunjukkan kesulitan yang dihadapi oleh anak-anak yang terkena dampak dan terinfeksi

Pengobatan HIV/AIDS merupakan pengobatan seumur hidup sehingga keberlangsungan pengobatan sangat berpengaruh terhadap hasil pengobatan. Permasalahan dalam pengobatan HIV/AIDS adalah ARV hanya untuk menekan replikasi virus, kesulitan dalam mendapatkan obat, kepatuhan pasien yang rendah dalam mengikuti program pengobatan, kurangnya informasi dan pemahaman tentang HIV/AIDS dan harga obat ARV yang mahal. ARV generik buatan Indonesia sudah tersedia namun belum Stigma terhadap HIV/AIDS masih cukup tinggi. Tidak mudah bagi masyarakat untuk menerima penderita HIV AIDS hidup secara normal di tengah-tengah mereka. Ketakutan akan terjadinya penularan serta keyakinan bahwa penderita akan memberikan kesialan pada lingkungan mereka, merupakan tantangan

\footnotetext{
* Corresponding author

(Email: sg_atik@yahoo.co.id)
}

HIV/AIDS. Akses mereka ke pelayanan pendidikan dan kesehatan mengalami keterbatasan karena diskriminasi, kesulitan keuangan keluarga karena penyakit, kesehatan anak yang buruk dan kebutuhan untuk merawat orang tua yang sakit. ${ }^{1}$

Anak dengan HIV merupakan kelompok rentan yang perlu dilindungi, mengingat orang tua mereka sering kali sudah meninggal karena HIV/AIDS sehingga menjadi beban keluarga atau kerabat. Berdasarkan Undang-Undang No.23 tahun 2002 tentang Perlindungan Anak menyatakan bahwa segala kegiatan untuk menjamin dan melindungi anak dan hak-haknya agar dapat hidup, tumbuh, berkembang, dan berpartisipasi secara optimal sesuai dengan harkat dan martabat kemanusiaan, serta mendapat perlindungan dari kekerasan dan diskriminasi. Negara dan pemerintah berkewajiban dan bertanggung jawab memberikan dukungan sarana dan prasarana dalam penyelenggaraan perlindungan anak. Anak adalah seseorang yang belum berusia 18 tahun, termasuk anak yang masih dalam kandungan. $^{3} \quad$ Oleh karena itu program pengobatan anak khususnya anak dengan HIV merupakan salah satu bentuk perlindungan anak.

didukung oleh kesiapan tenaga medis dan apoteker dalam mendukung keberhasilan terapi. ${ }^{4}$ Studi yang dilakukan oleh UNICEF dan Komisi Penanggulangan AIDS Nasional menunjukkan kesulitan yang dihadapi oleh anak-anak yang terinfeksi HIV/AIDS untuk mengakses pelayanan pendidikan dan kesehatan disebabkan oleh adanya diskriminasi, kesulitan keuangan keluarga, kesehatan anak yang buruk dan kebutuhan untuk merawat orang tua yang juga terinfeksi HIV-AIDS. ${ }^{1}$ dalam menangani dampak sosial HIV AIDS. ${ }^{5}$ Anak penderita HIV/AIDS adalah kelompok yang paling sering mendapat perlakuan diskriminatif di Indonesia. Sebagian besar malah tidak bersekolah atau dikucilkan masyarakat. ${ }^{6}$ 
Karena stigma dan diskriminasi, mereka tidak mendapatkan akses yang layak untuk layanan kesehatan dan pendidikan dan mereka bisa mengalami stigma atau ditolak oleh keluarga mereka sendiri. ${ }^{7}$

Anak-anak penderita HIV AIDS tentu akan dirugikan manakala mereka ditolak di sekolahsekolah karena ketakutan guru akan penularan virus. Namun apabila satus HIV mereka tidak disampaikan, maka tidak menutup kemungkinan anak-anak lain di sekolah tersebut akan terancam tertular melalui transmisi darah walaupun hal tersebut tidak mudah. Sementara pada isu HIV/AIDS, jelas, anak adalah korban karena mereka telah membawa virus ini sejak dilahirkan. Namun mereka tidak dapat menikmati perlakuan yang wajar dari lingkungannya karena menderita HIV positif. ${ }^{5}$

Artikel ini merupakan bagian dari penelitian "Akses Pengobatan HIV/AIDS dan Infeksi Oportunistik pada Anak di Sepuluh Kabupaten/Kota di Indonesia" yang dilakukan pada tahun $2015 .^{8}$ Tujuan penelitian ini adalah mengetahui gambaran stigma dan diskriminasi pada Anak Dengan HIV AIDS (ADHA) di sepuluh kabupaten/kota. Stigma adalah suatu perbedaan-perbedaan yang merendahkan yang secara sosial dianggap mendiskreditkan, dan dikaitkan dengan berbagai stereotip negatif. Sedangkan diskriminasi adalah aksi-aksi spesifik yang didasarkan pada berbagai stereotip negative yakni aksi-aksi yang dimaksudkan untuk mendiskreditkan dan merugikan orang. Stigma dalam prakteknya dianggap sebagai tantangan (stigmatisasi), sehingga orang harus dijatuhkan/direndahkan, atau dikucilkan (diskriminasi). ${ }^{9,10}$ Diharapkan artikel ini dapat menjadi evidence based bagi pemerintah dan stakeholder terkait untuk mengurangi stigma pada penderita HIV/AIDS dan upaya untuk meningkatkan kesejahteraan ADHA.

\section{METODE}

Disain penelitian yang digunakan adalah dengan menggunakan pendekatan gabungan kuantitatif dan kualitatif (mixed methods approaches). Lokasi penelitian dipilih secara purposive sampling yaitu rumah sakit rujukan HIV/AIDS di sepuluh kabupaten/kota yang termasuk dalam 5 besar provinsi dengan jumlah penderita HIV-AIDS terbanyak, yaitu Provinsi DKI Jakarta (Jakarta Utara, Jakarta Barat), Jawa Timur (Kota Surabaya, Kabupaten Malang), Bali (Kota Denpasar, Kabupaten Buleleng), Papua (Kota Jayapura, Kabupaten Jayapura) dan Sumatera Utara (Kota Medan, Kabupaten Deli Serdang). Sebagai sampel kuantitatif dalam penelitian ini adalah orangtua/wali dengan ADHA berusia $\geq 18$ bulan sejumlah 201 ADHA, sampel diambil dari data Sistem Informasi HIV/AIDS (SIHA) di setiap Dinas Kesehatan kabupaten/kota yang dipilih. Variabel kuantitatif dalam penelitian ini adalah karakteristik ADHA (usia, status anak, pendamping ADHA dan sumber penularan), alasan menutup status ADHA dan alasan membuka status ADHA. Pemakaian usia anak $\geq 18$ bulan dalam penelitian ini karena pada usia $<18$ bulan pemeriksaan HIV idealnya dilakukan pengulangan uji virologis HIV, sedangkan pada usia $\geq 18$ bulan bisa dilakukan pemeriksaan HIV seperti orang dewasa. Sedangkan untuk informan kualitatif dalam penelitian ini adalah dokter, perawat, manajer kasus, LSM, dan Dinas Pendidikan.

\section{HASIL}

\section{Studi Kuantitatif}

Pengumpulan data penelitian ini dilakukan secara kuantitatif dan kualitatif. Berdasarkan hasil kuantitatif untuk karakteristik ADHA, secara keseluruhan mayoritas usia ADHA berada di usia 5-9 tahun $(41,8 \%)$, berstatus masih sekolah $(58,7 \%)$, pendamping ADHA adalah orangtua kandung $(61,7 \%)$ dan sumber penularan HIV berasal dari Ibu (91,5\%). Tabel 1 
Tabel 1 Distribusi Frekuensi Penggunaan Kontrasepsi, Jenis Kontrasepsi, Obesitas pada WUS, Umur, Pendidikan, Status Pekerjaan dan Lama Penggunaan Kontrasepsi

\begin{tabular}{lrr}
\hline \multicolumn{1}{c}{ Uraian } & Jumlah & $\%$ \\
\hline Usia & & \\
18 bulan - 4 tahun & 57 & 23,8 \\
$5-9$ tahun & 100 & $\mathbf{4 1 , 8}$ \\
$>10$ tahun & 44 & 18,4 \\
Status anak & & \\
Tidak/Belum sekolah & 79 & 39,3 \\
Sekolah & 118 & $\mathbf{5 8 , 7}$ \\
Bekerja & 4 & 2,0 \\
Pendamping ADHA & & \\
Orangtua kandung & 124 & $\mathbf{6 1 , 7}$ \\
Nenek/Kakek & 32 & 15,9 \\
Paman/Bibi & 21 & 10,4 \\
Tanpa pendamping & 12 & 6,0 \\
Lainnya & 12 & 6,0 \\
Sumber Penularan & & $\mathbf{9 1 , 5}$ \\
Ibu & 184 & 7,0 \\
Hubungan seksual & 14 & 1,0 \\
Jarum suntik/IDU/penasun & 2 & 0,5 \\
Transfusi darah & 1 & $\mathbf{1 0 0 , 0}$ \\
\hline Jumlah & $\mathbf{2 0 1}$ & \\
\hline
\end{tabular}

Stigma dan diskriminasi mendorong orang tua/wali ADHA menyembunyikan status ADHA kepada lingkungan ADHA maupun terhadap ADHA sendiri. Dari 201 ADHA yang berusia $>18$ bulan, 54 menutup status dan 147 status sudah terbuka. Tabel berikut menggambarkan alasan menutup status ADHA (menyembunyikan status ADHA kepada lingkungan) dan membuka status ADHA (lingkungan mengetahui status ADHA) dapat dilihat pada tabel 2 dan 3 di bawah ini.

Tabel 2. Alasan menutup status ADHA terhadap HIV/AIDS di 10 Kabupaten/Kota di Indonesia, 2015

\begin{tabular}{lrr}
\hline \multicolumn{1}{c}{ Alasan } & Jumlah & $\%$ \\
\hline Malu/stigma/diskriminasi & 42 & 57,5 \\
Belum waktunya & 8 & 10,9 \\
Merasa tidak penting dibuka & 4 & 5,5 \\
Lain-lain & 19 & 26,1 \\
\hline
\end{tabular}

Tabel.3 Alasan membuka status ADHA terhadap HIV/AIDS di 10 Kabupaten/Kota di Indonesia, 2015

\begin{tabular}{lrr}
\hline \multicolumn{1}{c}{ Alasan } & Jumlah & $\%$ \\
\hline Keluarga sudah tahu & 113 & 45,9 \\
Butuh dukungan & 81 & 32,9 \\
Cepat atau lambat akan tahu & 28 & 11,4 \\
Lain-lain & 24 & 9,8 \\
\hline
\end{tabular}


Ketakutan, stigma dan diskriminasi terhadap ODHA (orang yang hidup dengan HIV/AIDS) masih menjadi hambatan utama. Keluarga dan anak-anak yang hidup dengan HIV/AIDS rentan terhadap stigma dan diskriminasi, yang dapat dilihat dari berkurangnya akses ke layanan, kehilangan martabat dan meningkatnya kemiskinan dan deprivasi.

\section{Studi Kualitatif}

Dari hasil penelitian kualitatif di 10 kabupaten/kota masih terjadi stigma dan diskriminasi pada ADHA. Hasil kualitatif, menunjukkan stigma dari masyarakat bisa berasal dari keluarga terdekat, teman dan tetangga. Stigma dari keluarga diterima ADHA dalam bentuk diskriminasi dan pembiaran. Diskriminasi terjadi karena keluarga takut tertular infeksi virus HIV, bentuk diskriminasi seperti tidak diperbolehkan makan bersama. Sedangkan pembiaran oleh keluarga yang diterima ADHA berupa ditinggal oleh orangtuanya di panti asuhan atau diserahkan ke neneknya.

"Ada kasus, neneknya sudah meninggal, mereka tinggal dengan tantenya, anak tantenya yang sebaya tidak diperbolehkan makan bareng, takut nular, walaupun sudah diberi tahu tidak nular" (LSM Kota Surabaya)

"Macam-macam keluarga, ada yang bisa menerima dan ada juga tidak, ada yang ditinggal bapak dan ibunya, dan harus tinggal sama neneknya dan ada juga yang membuang dan ditinggalkan di panti"(LSM Kota Surabaya)

Namun ada pula keluarga yang tidak bisa menerima kenyataan kalau anggota keluarganya terinfeksi HIV dengan mengingkari kenyataan. Pengucilan oleh keluarga kadang terjadi pada ADHA Remaja.

"Ada keluarga yang tahu tetapi menyangkal bukan sakit HIV tetapi sakit IMS" (LSM Kabupaten Malang)
"Keluarga kebanyakan belum bisa terima, ada yang 1 keluarga menolak kalau di diagnosa HIV/AIDS" (LSM Jayapura)

Selain keluarga terdekat stigma juga terjadi di lingkungan sekitar dan sekolah. Akibat stigma dari lingkungan sekitar (tetangga) terjadi diskriminasi berupa pengusiran keluarga ADHA dari lingkungannya. Sedangkan di lingkungan sekolah, sebagian besar ADHA yang bersekolah masih menutup statusnya. Bentuk diskriminasi yang diterima ADHA di sekolah adalah dikucilkan, tidak boleh bermain dan makan bersama bahkan sampai dengan dikeluarkan dari sekolah.

"Orang tua takut kalau statusnya di ketahui oleh warga, mereka biasanya kalau ambil obat cepat saja dan langsung pulang, dan mereka kalau diketahui oleh tetangga tempat tinggal mereka bisa diusir dan tidak boleh tinggal bersama warga yang lain. Itu ada sekitar 1-2 \% yang diusir kalau ketahuan." (Konselor RS Rujukan Kota Jayapura)

"Pendidikan banyak terkendala. Biasanya mereka masih closed status untuk keamanan dan kenyamanan. Karena di Medan, stigma masih tinggi baik dimasyarakat maupun di lingkungan sekolah." (LSM Medan Plus)

"Beberapa pasien lingkungan rumahnya tidak tahu, tapi sebagian ada yang tahu dan dikucilkan. Di sekolah yang tahu diejek oleh teman-temannya" (LSM Kabupaten Malang)

"Pernah juga ada anaknya yang bilang saya HIV, tapi gurunya ga apa-apa. Tapi pernah juga ada anak mau masuk SMP swasta, buka status. Sebenarnya sudah diterima, tetapi setelah buka status ditunda penerimaannya dan akhirnya ditolak." (LSM, Jakarta Barat)

Sementara itu Dinas Pendidikan masing-masing Kabupaten/Kota menyikapi positif bila ada anak didik yang positif HIV, yaitu dengan melindungi, merangkul dan membimbing ADHA. Seperti membantu sosialisasi mengenai HIV kepada orangtua ADHA. Membantu 
merahasiakan status ADHA hanya orangtua yang tahu. Bila terlanjur teman-temannya tahu, Dinas Pendidikan akan membantu kepindahan ADHA ke sekolah lain. Selain itu Dinas Pendidikan juga melakukan koordinasi dengan Dinas Kesehatan, Komisi Penanggulangan AIDS (KPA) dan Lembaga Swadaya Masyarakat (LSM) yang mengurusi HIV agar ADHA tetap bisa berobat, tidak terganggu proses belajarnya dan tidak dijauhkan oleh teman-temannya.

"Kalau ada anak yang terjangkit pasti kita harus rangkul dan sosialisasi kepada orang tua dan jangan dikucilkan dan membimbing dengan kegiatan kerohanian. Dan menjaga agar teman temannya jangan tau. kalau ada yang terkena di kabupaten maka akan diambil suatu kebijakan untuk dipindahkan ke sekolah lain,jadi kalau pendidik sendiri yang boleh tau adalah Kepala sekolah, sedangkan untuk guru itu juga tidak boleh kasih tau" (Dinas Pendidikan Jayapura)

"Koordinasi dengan Dinkes dan LSM untuk mengambil langkah-langkah agar anak dengan HIV/AIDS ini tidak terganggu proses pembelajarannya di sekolah, dan tidak dijauhkan oleh teman-temannya" (Dinas Pendidikan Kota Denpasar)

"Kalau terbukti positif HIV suruh pengobatan tidak mungkin kita mengeluarkan dari sekolah, kita suruh pengobatan dulu” (Dinas Pendidikan Jakarta Barat)

Hambatan psikologis dan sosial, menjadi hambatan dalam pengobatan HIV/AIDS di beberapa Kabupaten/Kota. Hambatan psikologis berupa stigma yang datang dari diri pasien sendiri (self stigma). Menurut petugas kesehatan, bentuk dari self stigma adalah tidak membuka status karena takut dan malu bila ketahuan penyakitnya. Dampak dari self stigma tersebut adalah tidak mau berobat karena takut diketahui orang, biasanya terjadi pada ADHA yang remaja. Sedangkan hambatan sosial adalah stigma yang diterima ADHA dari pelayanan kesehatan, seperti ADHA diperlakukan berbeda dengan pasien non HIV, menolak melayani pasien ADHA, bahkan ada petugas kesehatan yang masih khawatir untuk sekedar berjabat tangan dengan ADHA. Akibat perlakuan tersebut, menyebabkan pasien HIV enggan melakukan pengobatan.

"Stigma dari diri pasien sendiri misalnya minta pelayanan khusus, minta dipisah nggak mau campur dengan pasien yang lain, ketakutan diketahui statusnya" (Dinkes Jakbar)

"Hambatan psikologis, kadang pasien malas ke Rumah Sakit, karena takut dan malu ketahuan penyakitnya. Hal ini menjadi hambatan secara psikologis" (KPAD DKI Jakarta)

"Hubungan dengan nakes cukup baik meskipun masih ada diskriminasi yang dilakukan oleh perawat di RS. Biasanya mereka memandang beda terhadap anak tersebut"(LSM Kabupaten Deli Serdang)

Namun tidak semua petugas kesehatan di beberapa Kabupaten/Kota melakukan diskriminasi terhadap pasien ADHA. Hubungan tenaga kesehatan dengan ADHA dan keluarga cukup dekat. Petugas kesehatan ramah, bahkan ADHA remaja berobat sendiri tanpa diantar orangtua atau walinya. Sementara di Papua, karena HIV sudah umum, hubungan petugas kesehatan dengan ADHA dan keluarganya tidak ada masalah.

"Nakes sangat dekat dengan ODHA dan keluarga" (LSM Jakarta Utara)

"Kayaknya mereka enjoy juga, karena mereka ramah-ramah, say hello, mereka enjoy mereka datang sendiri yang SMA, karena perawatnya juga ramah" (LSM Kota Surabaya)

"Baik-baik saja, tidak ada diskriminasi, karena di sini HIV sudah umum, hubungan baik, mereka selalu bilang: kamu mau hidup, mau sehat, minum obat supaya tidak drop, tidak terkapar" (LSM Papua) 


\section{PEMBAHASAN}

Hasil kuantitatif pada penelitian ini menggambarkan karakteristik ADHA yang sebagian besar usia anak terinfeksi HIV adalah di usia 4 sampai dengan 9 tahun $(41,8 \%)$, status anak sebagian besar masih bersekolah $(58,7 \%)$ dengan pendamping sebagian besar adalah orangtua kandung $(61,7 \%)$ serta sebagian besar ADHA tertular HIV dari ibu kandungnya $(91,5 \%)$. Dari data terlihat bahwa sebagian besar usia ADHA adalah 4 sampai dengan 9 tahun, hal ini kemungkinan karena kerusakan berat sistem kekebalan tubuh pada ADHA cenderung terlihat pada usia 7 sampai dengan 8 tahun. Sebagian besar ADHA tertular dari ibu kandungnya, karena sebagian besar anak dibawah usia 10 tahun tertular HIV dari ibu kandungnya, penularan dapat terjadi dalam kandungan, waktu melahirkan atau melalui menyusui. ${ }^{11}$

Dari hasil kuantitatif juga terlihat bahwa sebagian besar masih bersekolah dengan pendamping adalah sebagian besar orangtua kandung. Hal ini kemungkinan karena usia 4 sampai dengan 9 tahun adalah usia sekolah dan di usia tersebut masih membutuhkan pendampingan orangtua dalam pengobatan ARV. Menurut penelitian Sugiharti, dkk, dukungan dari orangtua dan keluarga dapat meningkatkan kepatuhan minum obat ARV bagi ODHA. Faktor keluarga biasanya menjadi pendukung utama ODHA. ${ }^{12}$ Sedangkan menurut Spiritia, kepatuhan minum obat adalah tantangan besar untuk anak karena banyak anak tidak mengerti mengapa mereka harus mengalami efek samping obat. Karena itu baik anak maupun dewasa membutuhkan lebih banyak dukungan. ${ }^{11}$

Pada Tabel 2 dan Tabel 3, terlihat bahwa alasan menutup status ADHA sebagian besar karena malu/stigma/diskriminasi dan alasan membuka status ADHA sebagian besar karena keluarga sudah tahu. Hal ini sesuai dengan penelitian Handayani, dkk terdapat 21 ODHA yang tidak memiliki stigma. Kemungkinan hal ini terjadi karena ODHA belum membuka diri tentang statusnya. Adanya stigma tersebut menyebabkan ODHA menutup statusnya. Beberapa alasan umum pengasuh anak-anak dengan HIV menutup status, yaitu: 1) Ketakutan anak yang terinfeksi menjadi tidak baik setelah terungkapnya status HIV, terutama dalam keluarga di mana diagnosis masih dirahasiakan; 2) Ketakutan terhadap stigma, penolakan, dan hilangnya dukungan oleh keluarga/komunitas; 3) Keinginan untuk melindungi anak dari kekhawatiran tentang masa depannya; 4) Kemungkinan bahwa beban mengerti status HIV-nya akan menyebabkan depresi atau masalah kesehatan mental; (5) Perasaan bersalah dan malu dapat mencegah pengasuh terinfeksi HIV mengungkapkan infeksi mereka sendiri untuk anak mereka. ${ }^{13}$

Selain menutup status ADHA, ada juga pendamping yang membuka status ADHA dengan alasan keluarga sudah tahu. Pengungkapan status HIV sangat penting manfaatnya, yaitu: 1) menghindari risiko peningkatan penularan HIV di antara pasangan seks; 2) Membantu mendapatkan tambahan dukungan, termasuk akses terhadap pengobatan dan membantu mengikuti program perencanaan kehamilan, penggantian pemberian makanan untuk bayi, perawatan dan perencanaan masa depan; 3) mempengaruhi orang lain yang masih takut pengungkapan dan meningkatkan pengetahuan tentang HIV dan transmisinya. ${ }^{13}$

Stigma terhadap HIV/AIDS masih cukup tinggi. Tidak mudah bagi masyarakat untuk menerima penderita HIV/AIDS hidup secara normal di tengah-tengah mereka. Ketakutan akan terjadinya penularan serta keyakinan bahwa penderita akan memberikan kesialan pada lingkungan mereka, merupakan tantangan dalam menangani dampak sosial HIV/AIDS. Anak-anak penderita HIV/AID tentu akan dirugikan manakala mereka ditolak di sekolahsekolah karena ketakutan guru akan penularan virus. Aang Sutrisna juga melaporkan tentang angka putus sekolah ADHA, karena alasan pendidikan dirasakan cukup, tidak punya biaya, malu, membantu orang tua dan lain sebagainya. ${ }^{14}$ Namun apabila status HIV mereka tidak disampaikan, maka tidak menutup kemungkinan anak-anak lain di sekolah tersebut akan terancam tertular melalui transmisi darah walaupun hal tersebut tidak mudah. Sementara pada isu HIV/AIDS, jelas, anak adalah korban karena mereka telah membawa virus ini sejak dilahirkan. Namun mereka tidak dapat menikmati perlakuan yang wajar dari lingkungannya karena menderita HIV positif. ${ }^{5}$

Hasil penelitian Muksin, dkk bahwa stigma oleh guru terhadap anak dengan HIV positif 
dapat berasal dari personal (personal determinant) yaitu pengetahuan guru tentang HIV dan AIDS, jenis kelamin guru, dan juga materi edukasi yang didapatkan oleh guru terkait HIV dan AIDS. Sedangkan variabel yang berasal dari lingkungan (environmental determinant) yang dapat memperngaruhi terjadinya stigma oleh guru terhadap anak dengan HIV positif adalah persepsi terhadap sikap teman dan kepala sekolah terhadap anak HIV positif. ${ }^{15}$

Stigma dan diskriminasi pada ADHA juga terjadi di pelayanan kesehatan. Berdasarkan hasil penelitian Darmoris, dkk di Kepulauan Bangka Belitung, bahwa 42,4 persen petugas kesehatan bersikap diskriminasi pada pasien ODHA. Dari hasil kualitatif Darmoris, dkk diketahui juga bahwa masih ada ODHA yang ditempatkan pada tempat tertentu (ruang isolasi) setelah mengetahui status HIVnya, masih ada petugas kesehatan yang menyalahkan ODHA setelah tahu faktor resiko ia terkena HIV dan dokter yang tidak merahasiakan status HIV seorang pasien. Menurut Darmonis, dkk, hal ini terjadi disebabkan pengetahuan yang masih kurang dan kepercayaan terhadap responden yang salah terutama tentang sumber dan cara penularan HIV. ${ }^{16}$

Diskriminasi dari petugas kesehatan juga terjadi di Temanggung dan kudus, terutama di RS Daerah. Selain di RS diskriminasi juga dilakukan oleh pegawai pemerintahan pada saat pendamping membutuhkan kelengkapan dokumen administrasi untuk perawatan di RS. Anak-anak yang hidup dengan virus HIV/AIDS sangat membutuhkan dukungan dari lingkungan terdekat, dan dalam hal ini lingkungan terdekat mereka adalah keluarga. Namun bila keluarga tersebut mengalami stigma dan diskriminasi dari masyarakat maka semakin susah bagi keluarga tersebut untuk membesarkan anakanaknya. ${ }^{17}$ Menurut Paryati dkk faktor-faktor yang mempengaruhi stigma tenaga kesehatan adalah tingkat pendidikan, persepsi, lama bekerja, tingkat pengetahuan, kepatuhan terhadap agama dan dukungan institusi dan faktor-faktor lain seperti umur, jenis kelamin, dan pelatihan tentang HIV/AIDS. ${ }^{18}$

Masalah psikologis ADHA telah menjadi perhatian dunia. Penelitian tentang penerimaan dukungan sosial dan kesulitan psikosial di China dilaporkan oleh YA. Hong dkk menyatakan bahwa dukungan sosial berhubungan positif dengan kesejahteraan sosial ADHA. Penelitian tentang dukungan sosial terhadap ADHA di Ghana juga melaporkan hal yang sama. ${ }^{19,20}$ ADHA membutuhkan dukungan sosial untuk pertumbuhan dan perkembangan jiwanya agar hidup lebih sejahtera. Mereka juga berhak mendapatkan hak yang sama untuk hidup sejahtera. Pemerintah, stakeholder terkait HIV/AIDS perlu memberi perhatian terhadap aspek dukungan sosial kepada ADHA

\section{KESIMPULAN}

Anak Dengan HIV-AIDS (ADHA) merupakan kelompok rentan yang harus dilindungi. Mereka berhak untuk dapat hidup dengan layak dan aman seperti anak - anak lainnya. Namun hasil penelitian ini menemukan masih terjadi stigma dan diskriminasi bagi ADHA, baik di lingkungan rumah, sekolah, maupun fasilitas pelayanan kesehatan.

\section{SARAN}

Sosialisasi melalui media massa perlu lebih ditingkatkan lagi, agar ADHA dapat terlindungi dari stigma dan diskriminasi. Bentuk dukungan social dapat berupa kesempatan belajar bagi ADHA sehingga perlu perhatian khusus dari Kementerian Pendidikan dan Kebudayaan untuk (ADHA), mengenai keberlanjutan pendidikannya agar dapat menjalankan pendidikannya dengan normal. Peran sentral Komisi Penanggulangan AIDS disemua tingkat pemerintahan melalui fungsi advokasi dan koordinasi yang dimilikinya akan menjadi salah satu kunci keberhasilan dalam mengelola masalah ADHA.

\section{UCAPAN TERIMA KASIH}

Ucapan terima kasih kami sampaikan kepada Kepala Teknologi Intervensi Kesehatan Masyarakat, Badan Litbangkes yang telah memberi ijin penggunaan data penelitian ini. Terima kasih juga kami sampaikan kepada ibu Tin Afifah selaku pembimbing, tim peneliti, para informan penelitian dan semua pihak yang membantu penelitian ini yang tidak bisa kami sebutkan satu per satu. 


\section{DAFTAR PUSTAKA}

1. Unicef indonesia. Ringkasan Kajian Respon Terhadap HIV \& AIDS.

Ringkasasn Kaji. 2012;1-6.

2. Kementerian Kesehatan RI. Statistik HIV AIDS. Jakarta; 2013.

3. RI P. Undang Undang RI No. 35 Tahun 2014, Tentang Perubahan Atas UndangUndang No. 23 Tahun 2002 Tentang Perlindungan Anak. 2014 p. 1-45.

4. Departemen Kesehatan RI. Pedoman Pelayanan Kefarmasian Untuk Orang HIV AIDS (ODHA). Jakarta: Departemen Kesehatan RI; 2006.

5. Zakarija A, Amelia P. Intervensi Care Support Treatmen Bersasaran Anak dengan HIV/AIDS: Sebuah Model Pendekatan Humanistik Bagi Anak dan Lingkungannya Dalam Menghadapi Stigma. J Peremp dan Anak. 1(1):1-7.

6. Satriawan Y. Anak Penderita HIV-AIDS Masih Terima Perlakuan Diskriminatif. Voa Indonesia. 2015;

7. Yayasan Lentera Pelangi. Lentera Pelangi. Jakarta;

8. Rini Sasanti H dkk. Akses Pengobatan HIV/AIDS dan Infeksi Oportunistik pada Anak di Sepuluh Kabupaten/Kota di Indonesia. Jakarta, Indonesia; 2016.

9. Suzanne M et al. A Comparison of HIV Stigma and Discrimination in Five International Sites : The Influence of Care and Treatment Resources In High Prevalence Settings. Soc Sci Med. :22718.

10. Butt L, Morin J, Numbery G, Peyon I, Goo A. Stigma dan HIV/AIDS di Wilayah Pegunungan Papua. Kerjasama Penelit antara Pus Stud Kependudukan-UNCEN, Abepura, Papua dan Univ Victoria, Canada. 2010;

11. Spiritia. ANAK dan HIV. 2014;

12. Sugiharti, Yuniar Y, Heny Lestary. Gambaran Kepatuhan Orang Dengan Hiv-
Aids (Odha) Dalam Minum Obat Arv Di Kota Bandung, Provinsi Jawa Barat, Tahun 2011-2012. J Kesehat Reproduksi. 2015;5(2 Ags):113-123.

13. WHO. What is the impact of HIV on families? Evid Decis. 2005;(December):24.

14. Sutrisna A. Child Poverty and Social Protection Conference Dampak HIV Pada Pendidikan Anak di Indonesia [Internet]. 2009. Available from: http://www.smeru.or.id/cpsp/Paper, Abstact, CV/0103_Aang-paper.pdf

15. Parut AA. Hubungan pengetahuan tentang HIV/AIDS dengan stigma terhadap ODHA pada siswa kelas XI SMK VI Surabaya. J Ners Lentera. 2016;4(2):106-13.

16. Darmoris, Shaluhiyah Z, BM Syamsulhuda. Diskriminasi Petugas Kesehatan terhadap Orang Dengan HIVAIDS di Provinsi Kepulauan Bangka Belitung. J Promosi Kesehat Indones. 2011;6(2):101-8.

17. Ernawati. Sikap Pengasuh Anak Balita Yang Terinfeksi Hiv / Aids. J Keperawatan Komunitas. 2013;1(1):62-73.

18. Paryati T, Raksanagara AS, Afriandi I, Kunci K. Faktor-faktor yang Mempengaruhi Stigma dan Diskriminasi kepada ODHA(Orang dengan HIV/AIDS) oleh petugas kesehatan : kajian literatur. Pustaka Unpad. 2013;(38):1-11.

19. Hong Y, Li X, Fang X, Zhao G, Lin X, Zhang J, et al. Perceived social support and psychosocial distress among children affected by AIDS in China. Community Ment Health J. 2010;46(1):33-43.

20. Doku PN, Dotse JE, Mensah KA. Perceived social support disparities among children affected by HIV/AIDS in Ghana: A cross-sectional survey. BMC Public Health [Internet]. 2015;15(1):1-10. Available from: https://bmcpublichealth.biomedcentral.co $\mathrm{m} / \mathrm{track} / \mathrm{pdf} / 10.1186 / \mathrm{s} 12889-015-1856-5$ 